\title{
Comparison of hearing thresholds of patients with advanced, and very advanced sensorineural type hearing loss using tone-evoked ABR
}

\author{
İleri ve çok ileri derece sensörinöral (S/N) işitme kaybı olan hastaların \\ işitme eşiklerinin tonal ABR ile karşılaştırılması \\ Rıza Dündar', Erkan Kulduk', Fatih Kemal Soy', Ahmet Erdem Kılavuz², \\ Engin Umut Sakarya ${ }^{3}$, Haşmet YazıcI ${ }^{4}$, Abdülkadir Eren ${ }^{5}$ \\ ${ }^{1}$ Department of Otorbinolaryngology, Kızltepe Government Hospital, Mardin, Turkey \\ ${ }^{2}$ Department of Otorhinolaryngology, Malazgirt Government Hospital, Mus, Turkey \\ ${ }^{3}$ Department of Otorbinolaryngology, Bozkur Government Hospital, Konya, Turkey \\ ${ }^{4}$ Department of Otorbinolaryngology, Faculty of Medicine, Balkesir University, Ballkesir, Turkey \\ ${ }^{5}$ Department of Audiology, Mardin Government Hospital, Mardin, Turkey
}

\begin{abstract}
Objective: In the present study, thresholds of airway tone-burst auditory brainstem response (ABR), and pure-tone audiometry were compared, and correlations between threshold values obtained with classical audiometric methods, and pure-tone airway hearing in individuals with advanced, and very advanced sensorineural $(\mathrm{S} / \mathrm{N})$ hearing loss were investigated.

Methods: Eighty patients with advanced and very advanced S/N hearing loss were included in the study. Pure-tone air conduction thresholds of advanced, and very advanced S/ $\mathrm{N}$ hearing loss patients detected at 500, 2000 and $4000 \mathrm{~Hz}$ frequencies were compared with tone-burst ABR threshold values.

Results: Our study population consisted of males with a mean age of 21.8 \pm 3.45 . Mean differences between thresholds of tone-burst, and pure-tone audiometry were detected to be $4.75 \mathrm{~dB}, 6.25 \mathrm{~dB}$, and $4.87 \mathrm{~dB}$ at stimulus frequencies of $500 \mathrm{~Hz}, 2000 \mathrm{~Hz}$, and $4000 \mathrm{~Hz}$, respectively. Conclusion: In conclusion, in patients with $\mathrm{S} / \mathrm{N}$ hearing loss, a strong correlation is found between pure-tone audiometry thresholds, and electrophysiological thresholds obtained at 500, 2000, and $4000 \mathrm{~Hz}$ with tone-evoked ABR wave-V. Tone-ABR can be used as a reliable test in the diagnosis of patients with hearing loss in conditions where pure-audiometry cannot be performed.
\end{abstract}

Keywords: Pure-tone audiometry, advanced sensorineural type hearing loss.

\begin{abstract}
Özet
Amaç: Bu çalışmada hava yolu tonal ABR ile saf ses hava yolu işitme eşiklerinin karşılaştırılması yapılarak; klasik odyometrik yöntemlerle ileri ve çok ileri derece sensörinöral $(\mathrm{S} / \mathrm{N})$ işitme kaybı olan kişilerin tonal ABR ile elde edilen eşiklerinin korelasyonu araştırılmıştır.

Yöntem: İleri ve çok ileri derece $\mathrm{S} / \mathrm{N}$ işitme kaybı olan 80 hasta çalışmaya dahil edildi. Saf ses ölçümlerinde ileri ve çok ileri derecede sensörinöral işitme kaybı hastaların 500, 2000 ve $4000 \mathrm{~Hz}$ 'te elde edilen saf ses hava yolu eşikleri ile tonal-ABR eşik değerleri arasında karşılaştırma yapild.

Bulgular: Çalışmaya alınan hastaların yaş ortalaması $21.8 \pm 3.45$ olarak saptandı ve tüm hastalar erkekti. Tonal ABR ve saf ses eşikleri arasında $500 \mathrm{~Hz}$ uyaran için ortalama fark $4.75 \mathrm{~dB}, 2000 \mathrm{~Hz}$ uyaran için $6.25 \mathrm{~dB}$ ve $4000 \mathrm{~Hz}$ uyaran için fark $4.87 \mathrm{~dB}$ bulunmuştur.

Sonuç: Sonuç olarak ileri derece $\mathrm{S} / \mathrm{N}$ işitme kaybı olan bireylerde saf ses odyometri eşikleri ile 500, 2000 ve $4000 \mathrm{~Hz}$ tonal ABR V.dalga ile elde edilen elektrofizyolojik eşikler arasında güçlü bir korelasyon vardır. Tonal ABR, saf ses odyometri yapılamadığı durumlarda, işitme kaybı olan hastaların tanısında güvenilir bir test olarak kullanılabilir.
\end{abstract}

Anahtar sözcükler: Saf ses odyometri, ileri derecede sensörinöral işitme kayb1.
Correspondence: Erkan Kulduk, MD. Department of Otorhinolaryngology, Mardin Government Hospital, Mardin, Turkey .

e-mail: erkankulduk@yahoo.com

Received: June 14, 2014; Accepted: July 11, 2014
Online available at:

www.jmedupdates.org doi:10.2399/jmu.2014002005 QR code: 
Hearing is one of the important functions which enables adaptation, and communication of the organism with its environment. Sensorineural hearing $(\mathrm{S} / \mathrm{N})$ is realized with the aid of cochlear cilia, and neurons, pathways up to the cerebral cortex, and their integration. Interference to the functions of one of these components for various reasons leads to $\mathrm{S} / \mathrm{N}$ hearing loss. As etiological factors of this interference genetic (syndromic, non-syndromic), congenital infections (rubella, CMV), infections (rubeola, measles, toxoplasmosis, syphilis), ototoxicity, exposure to noise, and presbiacusia have been suggested. ${ }^{[1]}$

Frequently, and prevalently applied first test for the detection of hearing sensitivity in adult patients is pure-tone audiometry. Pure-tone audiometry detects the type, and severity of the hearing loss. In the detection of airway hearing threshold, the average of the airway hearing thresholds at $500-1000 \mathrm{~Hz}$, and $2000 \mathrm{~Hz}$ is taken into consideration. ${ }^{[2]}$ Data which can be obtained using pure-tone audiometry are related to the hearing thresholds, the laterality, and the type of the hearing loss, and the frequencies affected. ${ }^{[\beta]}$ Although this test is not one of the objective hearing tests, it is an indispensable audiologic test in the orientation of diagnostic, follow-up, and therapeutic processes.

Evoked auditory brainstem potentials is an objective test which is used for the determination of hearing thresholds in pediatric cases who cannot comply with pure-tone audiometry tests or in adults, and children who make simulation or cannot show cooperation on the test for any reason (ie. mental retardation). Auditory brainstem response (ABR) audiometry is a battery of tests, which enable objective evaluation of auditory potentials stemming from the structures at a level of VIII cranial nerve, and lower brainstem following acoustic stimuli. In the determination of hearing threshold, ABR provides information about the peripheral hearing sensitivity. In ABR, tonal stimulus is the most important stimulus in obtaining frequency-specific response.

In the present study, thresholds of airway tone-burst $\mathrm{ABR}$, and pure-tone audiometry were compared, and correlations between threshold values obtained with classical audiometric methods, and pure-tone airway hearing in individuals with advanced and very advanced $\mathrm{S} / \mathrm{N}$ hearing loss were investigated.

\section{Materials and Methods}

This study was performed between May 2005 and June 2007 in the Laboratory of Evoked Auditory Potential of Ear-Nose and Throat Department of Gülhane Military
Medicine Academy (GATA). Among 85 patients with advanced and very advanced S/N hearing loss, only 5 cases with a history of operation were not included in the study. Demographic, and clinical data of the patients were recorded. The study was approved by the ethics committee. The patients were firstly subjected to pure-tone audiometry, then tone-burst ABR (tone-ABR) test was performed, and hearing threshold values were estimated. Patients with completely healthy eardrums as detected by otoscopic examinations were included in the study. In every patient with suspect retrocochlear pathologies, CT was used to rule out this possibility. Classical audiometric tests were performed by IAC AC-5 model clinical audiometry equipment. For ABR analysis, Nicolet Compact Auditory model electrodiagnostic system was used.

For the retrieval of tone-ABR recordings, 4 mm-diameter silver electrodes were used. During testing, active, and ground electrodes were placed on the forehead, and reference electrode on the ipsilateral mastoid cortex. Electrode impedances were attentively kept under $5 \mathrm{~K} \Omega$. All cases were sedatized with $0.01 \mathrm{mg} / \mathrm{kg} \mathrm{IM}$ midazolam (Dormicum) during enrolment. Tone- burst stimuli with alternant polarity were used. Rise/fall/plateau times of tonal stimuli were selected as $1-8-1 \mathrm{~ms}$. ABR pure-tone average, and duration of analysis were determined, and set at $2000 \mathrm{~ms}$, and $20 \mathrm{~ms}$, respectively. During tests EEG upper, lower cut-off values of filter settings were selected as 30 , and $3000 \mathrm{~Hz}$, and duration of analysis as $25 \mathrm{~ms}$. Tone- burst ABR stimuli were delivered at frequencies of 500, 2000, and $4000 \mathrm{~Hz}$. High-pass, and low-pass ABRs were filtered at frequencies of 30 , and $1500-3000 \mathrm{~Hz}$, respectively.

Pure-tone air conduction thresholds of advanced and very advanced $\mathrm{S} / \mathrm{N}$ hearing loss patients detected at 500 , 2000 and $4000 \mathrm{~Hz}$ frequencies were compared with toneABR threshold values. Pure-tone audiometry tests of the same individual were performed twice in the same ambient conditions using threshold values.

Recorded test data were subjected to statistical analysis. Mean values, and standard deviations were calculated. Mean values for gender, age of the patients, recordings for right, and left ears were compared using Student's t test. Since ABR threshold values were different, and scattered noncompliant with normality of distribution, nonparametric statistical tests were used. The correlation between tone-ABR, and pure-tone audiometry thresholds was analyzed using Spearman's rank order test. 


\section{Results}

Ages of the patients included in the study ranged between 18 , and 26 years. Our study population consisted of males with a mean age of $21.8 \pm 3.45$.

To determine threshold of tone-ABR, wave- $\mathrm{V}$ was evaluated. In 58 (72.5\%) patients with very advanced hearing loss as detected by pure-tone audiometry, stimuli at a high intensity ( $90 \mathrm{~dB} \mathrm{nHL}$ ) did not elicit any response in auditory-evoked brainstem audiometry (wave- $\mathrm{V}$ could not be detected). In 20 patients with very advanced S/N hearing loss, stimuli at $90 \mathrm{~dB} \mathrm{nHL}$ yielded a response. One $(1.25 \%)$ patient responded to stimuli at an intensity of 80 $\mathrm{dB}$ nHL, and frequency of $500,2000 \mathrm{~Hz}$, while another patient yielded a response to stimuli at an intensity of 80 $\mathrm{dB} \mathrm{nHL}$, and frequencies of 500, 2000, and $4000 \mathrm{~Hz}$. The wave- $\mathrm{V}$ was distinctly recognized, and defined at a level of $90 \mathrm{~dB} \mathrm{nHL}$ which was determined as the threshold value. Mean absolute latencies of wave- $\mathrm{V}$ of the patients with very advanced hearing loss $(75-90 \mathrm{~dB})$ when the patient was exposed to a stimulus at a level of $90 \mathrm{~dB} \mathrm{nHL}$ were determined as $11.06 \pm 1.40 \mathrm{~ms}, 8.80 \pm 0.50 \mathrm{~ms}$, and $8.60 \pm 0.70 \mathrm{~ms}$, at frequencies of $500 \mathrm{~Hz}, 2 \mathrm{kHz}$, and $4 \mathrm{kHz}$, respectively.

When all patient population was considered, mean differences between thresholds of tone-burst, and pure-tone audiometry were detected to be $4.75 \mathrm{~dB}, 6.25 \mathrm{~dB}$, and 4.87 $\mathrm{dB}$ at stimulus frequencies of $500 \mathrm{~Hz}, 2000 \mathrm{~Hz}$, and 4000 $\mathrm{Hz}$, respectively.

Spearman's rank test was used to analyze the correlation between thresholds of tone-ABR, and pure-tone audiometry at stimulus frequencies of 500-2000, and 4000 $\mathrm{Hz}$, then correlation coefficients between thresholds were calculated for each frequency. $p$ values showed statistically significant and strong correlation $(\mathrm{p}=0.945 ; \mathrm{p}=0.962$; $\mathrm{p}=0.985)($ Table 1$)$.

\section{Discussion}

Since evaluation of hearing using behavioral audiometry is based on patients' self-reported information, it is a subjec-

Table 1. Correlation between thresholds of tone-ABR, and pure-tone audiometry at stimulus frequencies of 500-2000, and $4000 \mathrm{~Hz}$.

\begin{tabular}{lccc}
\hline & $\mathbf{5 0 0 ~} \mathbf{~ z z}$ & $\mathbf{2 0 0 0 ~} \mathbf{~ z}$ & $\mathbf{4 0 0 0 ~} \mathbf{~ z}$ \\
\hline Tone-ABR (dB nHL) & 89.75 & 89.75 & 89.87 \\
Pure-tone audiometry (dB HL) & 85 & 83.5 & 85 \\
p value & 0.945 & 0.962 & 0.985 \\
\hline
\end{tabular}

tive test. It is not possible for an individual to evaluate his/her actual behavioural threshold completely, and exactly independent from one's feelings. Though its application is more difficult, and time consuming than other tests, in conditions where determination of threshold is complicated with other factors, ABR is a valid, and objective method for the measurement of hearing thresholds.

Stapells et al. detected that when compared with puretone audiometry thresholds tone-ABR thresholds were 10-20 dB nHL higher in individuals with normal hearing acuity, while in individuals with sensorineural hearing loss this increment was $5-15 \mathrm{~dB} \mathrm{nHL}^{[4]}$ In our study, in patients with very advanced $\mathrm{S} / \mathrm{N}$ hearing loss, a difference of 4-6 dB nHL was found.

Durgut et al. detected differences of $13,7,8 \mathrm{~dB}$ between thresholds of tone-burst $\mathrm{ABR}$, and pure-tone audiometry applied at 500,2000, and $4000 \mathrm{~Hz}$, respectively in individuals with normal hearing acuity, while the corresponding differences in patients with sensorineural hearing loss were 13,7 , and $8 \mathrm{~dB} .{ }^{[5]}$ They did not include patients with very advanced hearing loss in their study. In our study the respective differences were $4.75,6.25$, and $4.87 \mathrm{db}$, respectively.

Kisat et al. compared pure-tone audiometry thresholds with tone-burst ABR thresholds with rise/fall/plateau times of 1-1-1, 1-2-1, 1-4-1, and 1-8-1 ms duration in 10 individuals with normal hearing acuity, and 21 patients with sensorineural hearing loss. They noted a 3-18 dB difference between thresholds of tone-burst ABR, and puretone audiometry. They detected that as the frequency increased, the difference between thresholds of ABR, and pure-tone audiometry decreased, and especially when tone-ABR stimuli with 1-8-1 ms were used. However in higher frequencies, thresholds of $\mathrm{ABR}$, and pure-tone audiometry were close to each other. In patients with sensorineural hearing loss, and flat audiograms, they detected that difference between thresholds of pure-tone audiometry, and tone- burst ABR ranged between 2.5, and $25 \mathrm{~dB}$. They observed better outcomes in lower frequencies. ${ }^{[6]}$

In many studies, consistent results have been obtained regarding differences between the thresholds of tone burst $\mathrm{ABR}$, and pure-tone audiometry. The results retrieved have demonstrated differences owing to the diverse methodologies used.

Generally, the longer is the rise/fall, and plateau times of tone burst stimuli, the frequency range generated in the cochlea induced by these stimuli narrows proportionally. 
Therefore stimulus tends to stimulate cochlea within a narrow band of frequencies, and thus selectivity for frequency predominates. Because of weakness of synchronized activities induced by these types of stimuli, the amplitudes of predetermined responses, and their detection rates decrease. However, tone-burst stimuli with relatively shorter rise/fall times evoke better synchronized responses. Since these types of stimuli induce wider spectral scattering, they are subjected to interference from other frequencies. Consequently, wave recognizability is increased, at the risk of decreased frequency-specificity. ${ }^{[7,8]}$ Besides studies performed have detected that response latency is prolonged in proportion with increased rise/fall times. ${ }^{[9-1]}$ In our study, among patients with advanced hearing loss, number of recognizable waves increased without a marked prolongation of latency.

\section{Conclusion}

In conclusion, in patients with $\mathrm{S} / \mathrm{N}$ hearing loss, a strong correlation is found between pure-tone audiometry thresholds, and electrophysiological thresholds obtained at 500,2000 , and $4000 \mathrm{~Hz}$ with tone-evoked ABR wave-V. Tone-ABR can be used as a reliable test in the diagnosis of patients with hearing loss in conditions where pureaudiometry cannot be performed.

Conflict of Interest: No conflicts declared.

\section{References}

1. Çelik O. KBB hastalıkları ve baş boyun cerrahisi. İzmir: Asya Tıp Yayınevi; 2007. p. 12-3.

2. Jerger J, Jerger S. Measuring of hearing in adults. In: Paparella MM, Shumrick DA, editors. Otolaryngology. 2nd ed. Philadelphia: WB Saunders; 1980. p. 1226.

3. Jacobson JT, Northern JL (Editors). Diagnostik audiology. Texas: Pro-ed; 1991; p. 3-18.

4. Stapells DR, Picton TW, Durieux-Smith A, Edwards CG, Moran LM. Thresholds for short-latency auditory-evoked potentials to tones in notched noise in normal-hearing and hearing-impaired subjects. Audiology 1990;29:262-274.

5. Durgut $M$. Normal işiten ve sensorinöral işitme kayıplı erişkin bireylerde tonal beyinsapı işitsel uyarılmış potansiyelleri ile elde edilen eşiklerin saf ses odyometriyle elde edilen eşiklerle karşilaştirilmasi. Dokuz Eylül Üniversitesi Sağlık Bilimleri Enstitüsü, Yüksek Lisans Tezi, İzmir, 2010.

6. Kısat F, Yetişer S, Muş N. Basit tonal-ABR ile objektif odyogram elde etmede kullanılan yöntemlerin karşılaştırılması. KBB ve Baş Boyun Cerrahisi Dergisi 1998;6:116-20.

7. Stapells DR. Frequency-specific evoked potential audiometry in infants In: Seewald RC, editor. A sound foundation through early amplification. Basel: Phonak AG; 2000. p. 13-31.

8. Suzuki T, Hirai Y, Horiuchi K. Auditory brainstem responses to pure tone stimuli. Scand Audiol 1977;6:51-6.

9. Stapells DR, Oates P. Estimation of the pure-tone audiogram by the auditory brainstem response: A review. Audiol Neurootol 1997;2:257-80.

10. Jacobson JT. Effect of rise time and noise masking on the tone pip auditory brainstem responses. Semin Hear 1983;4:363-72.

11. Jewett DL, Romano MN. Neonatal development of auditory system potentials avareged from the scalp of the rat and cat. Brain Res 1972;36:101-5.

This is an open access article distributed under the terms of the Creative Commons Attribution-NonCommercial-NoDerivs 3.0 Unported (CC BYNC-ND3.0) Licence (http://creativecommons.org/licenses/by-nc-nd/3.0/) which permits unrestricted noncommercial use, distribution, and reproduction in any medium, provided the original work is properly cited.

Please cite this article as: Dündar R, Kulduk E, Soy FK, Kılavuz AE, Sakarya EU, Yazıcı H, Eren A. Comparison of hearing thresholds of patients with advanced, and very advanced sensorineural type hearing loss using tone-evoked ABR. J Med Updates 2014;4(2):52-55. 